\title{
The Incompatibility of the Vision of God as a Basis of Factual Belief from Philosophical Perspective
}

\author{
INDRIATY ISMAIL ${ }^{1}$
}

\begin{abstract}
Religious people may feel confident that they have something that nonreligious people lack, namely, direct experience of God. They may claim that such religious experience, like visions of God, is a way of knowing God's existence. This claim has been examined by some scholars and philosophers in the field of philosophy of religion. The purpose of this writing is to analyze the reasonableness of believing in the existence of God on the basis of this claim. The methodological approach of gathering data is mainly through document analysis on various books of philosophy of religion and philosophy of God. This writing concludes that visions lack the consistency and predictability needed to form the basis of any factual belief.
\end{abstract}

Keywords: belief, philosophy, vision of God, religious experience

The first part of this writing span in general terms of what may be called the direct experience; vision of God. It takes into accounts the religious experiences that seem to indicate the feeling of the moment and then distinguishes between this direct perceiving of God and other kind of conscious experiences. The examples quoted in this part have been taken from various religions, mainly Christianity and Hinduism. Thereafter, in the second part of the writing, it tries to show how visions of God fail to provide evidence for religious claims. There will be four main reasons in arguing that this concept does not seem to be available to support any claim for the existence of God. The discussion will go on further to discuss the arguments that seem to give a cognitive status to the mystical experiences of God. However, the essay will finally conclude the discussion with the suggestion that the concept of vision of God lacks the consistency and predictability needed to form the basis of any factual belief at all.

\section{The Concept of Vision of God}

Religious experience is an umbrella term covering many different types of experience charismatic phenomena, numinous feeling, possession, conversion experience, mystical consciousness, visions, voices and so on. It is important here to look at the terminology involved in this discussion. The word vision means a mental picture of a possible situation or state of affairs, in which we imagine how things might be different from the way they are now. It is also a mental picture which you have as a result of divine inspiration, madness, or taking drugs (Cobuild 1989: 1627). In line with the above meaning, vision is one of the five main sensations - sight, hear, smell, taste and touch. All these kind of physical sensations, along with the intellectual processing (reasoning), are the fundamental characteristics or elements of the cognitive aspects of our ordinary consciousness. Vision, however, in this

${ }^{1}$ Indriaty Ismail, Ph.D. Senior Lecturer at the Department of Theology and Philosophy, Universiti Kebangsaan Malaysia, 43600 Bangi, Selangor, Malaysia, Email: indriaty@ukm.my.

https://doi.org/10.24035/ijit.2.2012.001 
context does not merely involve empirical objects which can be perceived by our sensory intellectual consciousness, but inclusive of the objects of supra-sensory. Actually, these kinds of objects are those divine being which could not be seen by our eyes as they are nonphysical. Because of the characteristic and they are seldom occur in our life, this kind of vision is totally different from that we normally experience.

Let us first consider the claims that the theologians have made. Some of their experiences are usually described as follows: "I have direct experience of God", "I saw a vision of Archangel Gabriel", "I seem to see the Blessed Virgin Mary", and 'I saw Christ at my side". These assertions are found among Christians and we will discuss later the visions of other religions. We should compare these assertions with the statement of seeing worldly objects, such as: "I saw a black horse", "I seem to see a red tomato", and "I see a car in front of the house". Firstly, we will start by examining the last three examples of the physical objects perceived by our ordinary visions. We can touch the black horse, taste the tomato and listen to the car engine. We can examine these objects with certainty by other physical sensations. On the whole, our sense experiences typically involve the conviction that the object on which the experience is focused and 'is really there', that it exists and that one 'experimentally' apprehends it. This conviction is not an interpretation which is placed upon the experience, but a part of the experience itself.

Obviously, as mentioned above, vision or perception requires a real object. Perception could be analyzed into a conscious experience (CE) of a perceiver (P), the object (O) perceived, and a relation (R) between the object and the perception. $R$ is a causal relation. $O$ causes CE or is an indispensable part of the cause (Matson 1965: 12-13). If the perceiver is prevented from perceiving any objects, for examples, the eyes are closed, or he is a blind man, no relations occur, and he perceives nothing, even if there happens to be an object in front of him. We can say that his claim of experiencing the objects is only an imagination or hallucination. The case is different when we look at the vision of God, of the Virgin Mary, and of the Archangel Gabriel. The Christians believe that God is sometimes present and shows Himself to the believer, in one of the various ways He chooses to. But we are so made that what we apprehend of the object is the sort of thing that could not be photographed, touched, smelled or seen by others. It is a special sort of things that is beyond all things and beyond our sensory-intellectual consciousness. It is by no means clear that the relation between sense experiences and physical objects are significantly different from the relations between mystical experiences and an object like God.

The way in which many theologians talk about their experiences seem to show that they think of knowing God as something requiring a kind of the sixth sense. The sixth sense is very different from the above five. For the Divine Being whom they claim to have seen, only exists, in the perceivers' experiences alone, and could not be justified by others (Martin 1973: 338). Returning for a moment to the case of sense experience, there is a checking procedure in 'seeing' the physical objects but not for the religious 'seeing'. The result of the checking procedure is always supportive of our claims and is confirmed by other people. But if, while checking over our proof, we find that they are unsuitable at all to the object perceived, for example, the horse is not black; we only say that, "I didn't really see, I only thought I did". We have so far encountered few differences between the ordinary vision and the vision of Divine Being. That religious vision has no causal efficacy, no relation between the subject and the object, vision is self certifying and no effective way could be used as a procedure in checking the vision. All these difficulties showed that this kind of experience does not involve the conviction that the object really exists and we really saw it. But, how can we prove the existence of the phenomenon that has happened and finished in the past; an experience which is not continual but a 'one-off' experience? 
In describing the content of our experiences, there occurs another problem of language. How could we describe the ineffable with a finite term? Surely, such language is inadequate. This leads the theologians to use metaphors. By using metaphors we emphasize the fact that often we come to understand the point of an argument or problem in logic suddenly. This then points to another difference between sense experience and mystical experience, where the conviction of the ontological interpretation is placed upon the experience, and not part of the experience itself.

All those difficulties are the major reasons why we should not say that visionary experience has cognitive value. As far as we see, all what we mean when we say that an experience is cognitive or perceptual, is that through this experience we come to know something which could not know, or could not know as easily, in other ways, and probably that the knowledge in question is non-inferential. In short, because the vision is naturally weak, we cannot base any factual belief on it and cannot rely on vision as a form of evidence of faith. We shall later deal with these factors in detail in the next part of the essay.

Now we come to the classical classification of vision made by the contemplative Catholic theologians. They distinguished three classes of vision; the external, the imaginary or the imaginably, and the intellectual. An external vision is one in which what appears, appears as part of the environment and may be confused with the ordinary world of things and people. An imaginary vision is one in which what appears, appears as an object of vision in some sense, but can be distinguished sharply from material objects. An intellectual vision is not a vision at all but a feeling of presence (Mac Intyre 1969: 254). Alasdair Mac Intyre, in his writing about Visions, reduced these three classifications to two classes. First, those visions which can properly be called such, that is, those where something is seen; and second, those where the experience is of a feeling-state or of a mental image, which are only called visions by a honorific extension of the term (Mac Intyre 1969: 255). An example may help us to understand the visions in discussion. It is clear that phenomenologically different visions have different contents. Much the greater part of the phenomenology of visions comes unmistakably from the very own scriptures and tradition of those experienced. St. Teresa of Avila, one of the classic contemplatives, was reported to value the intellectual visions the most highly and external visions at the least. She wrote:

I had the following experience. I was at prayer on a festival of the glorious Saint Peter when I saw Christ at my side - or to put it better, I was conscious of Him, for neither with the eyes of the body nor with those of the soul did I see anything. I thought He was quite close to me and I saw that it was He who, as I thought, was speaking to me ... All the time Jesus Christ seemed to be beside me, but, as this was not an imaginary vision. I could not discern in what form: what I felt very clearly was that all the time He was at my right hand, and a witness of everything that I was doing, and that, whenever I became slightly recollected or was not greatly distracted, I could not but be aware of His nearness to me (Peers 1957: 170).

It was well-known in the Bible, that the Prophet Isaiah saw a vision of Yahweh in the Temple. He explains: "Woe to me!" I cried. "I am ruined! For I am a man of unclean lips, and I live among a people of unclean lips, and my eyes have seen the King, the Lord Almighty" (Isaiah 6: 5). In Hinduism, Sri Rama Krishna experienced the vision of the Goddess Kali. Buddhists sometimes seek visions of celestial Buddha and Bodhisattvas (Bassuk 1987: 5). Early Jewish mystics cultivated visions of God's throne-chariot. Some people report spiritual 
experiences where they claim to have visions of God. Common reported experiences also include seeing light or a magnificent being seated on a throne.

In Islamic doctrine, God cannot be seen in this life but the believers will see God in the next life; even then, God will not be grasped in totally. This is stated clearly in the Quran: "On that day some faces will be bright, looking at their Lord" (Quran 75: 22-23). Rendering images of God in Islam in this life is impossibility and an amount to disbelief, as God tells in the Quran that nothing resembles Him (Quran 42: 11, 112: 4). The human mind is a true marvel but in certain areas it is limited. God is different from anything the human mind can think of or imagine, so the mind will become confused if it tries to picture God. Eyes cannot bear the vision of God. God tells in the Quran: "Vision cannot grasp Him, but His Grasp is over all vision" (Quran 6:103). Moses, to whom God spoke and gave great miracles, was chosen by God to be His Prophet. It is said that he thought that, since God used to speak to him, he might be able to actually see God. The story in the Quran tells us about the request of Moses to see God:

And when Moses arrived at our appointed time and his Lord spoke to him, he said, 'My Lord, show me (Yourself) that I may look at You'. (God) said, 'you will not see Me, but look at the mountain; if it should remain in place, then you will see Me.' But when His Lord appeared to the mountain, He rendered it level, and Moses fell unconscious. And when He awoke, he said, 'Exalted are You! I have repented to You, and I am the first of the believers' (Quran 7: 143).

God made it clear that no-one, including the great prophet Moses, can bear the sight of the divine, for God is too great to be grasped by human eyes in this life. According to the Quran, Moses realized his request was in error; therefore, he sought forgiveness from God for having asked. Did Prophet Mohammed see God in this life? Prophet Mohammed travelled in a miraculous journey through the heavens and met God. People thought that since Prophet Mohammed spoke to God in that journey, he probably saw God too. One of the companions, Abu Dahr, asked about it. The Prophet replied: "There was only light, how could I see Him?" (Sahih Muslim). To the question what was the light he saw, the Prophet explained: "Surely, God does not sleep nor it is befitting for Him to sleep. He is the one who lowers the scales and raises them. The deeds of the night go up to Him before the deeds of the day and those of the day before those of the night, and His veil is light" (Sahih Muslim).

As far as I am concerned, neither the scripture nor the traditions are found to have reported about Prophet Mohammed experienced a vision of God in His pure Essence. What we only know is about his auditory experience of Gabriel, who recites passages of what has to become the Quran (Quran 2: 97). There were also many claims from the Sufis or Islamic mystics of having a very personal experience of God, such as al-Hallaj and Ibn al-Arabi. Many Sufi masters felt that it was inappropriate to share their mystical experience with the masses, yet al-Hallaj openly did so in his writings and through his teachings. He falls into trances which he attributed 'to being in the presence of God'. During one of these trances, he would utter: أنا الحق; "I am The Truth", which was taken to mean that he was claiming to be God, since "The Truth" is one of the Ninety Nine Names of Allah. In another controversial statement, al-Hallaj claimed "There is nothing wrapped in my turban but God," and similarly he would point to his cloak and say, ما في جبتي إلا اله "There is nothing in my cloak but God" (Mason 1995). The above explanation is to suggest that the same experience of vision is being differently interpreted and described according to the beliefs of those experienced, traditions and cultures. The specific material out of which the vision is composed - the 
figure of an angel, or Christ, or Krishna, or Kali, or of a throne, a heart, a cloud, is supplied by the imagination and memory of the mystics.

There are indeed certain features of visionary experiences that appear crossculturally; the direct awareness of light and the relational awareness of height, depth and magnitude. These seem to have universal symbolic significance. However even the experience, for example, of seeing a bright light can take on a tradition-specific character. Thus, in many of the reports the 'being of light' is experienced by Christians, but not by people of other traditions, as the dazzling presence of Christ (Hick 1989: 166). We have seen in so far that vision as well as voices which are usually experienced at the time of seeing a vision of the God, is the peak experience of the mystics of different religions. This is to say that the sort of persons who are mystics may often be the sort of persons who see visions and hear voices. However, for many of the mystics these unusual experiences were unexpected. They are deeply concerned in prayers and devotions to their God. By the time their soul recognizes the presence of God, the recognition caused by the effect which God produces in their soul, the soul distinctively sees that God is present. They never aim nor dream to have all those experiences. A case in point is St. Teresa of Avila (Peers 1957: 171). No one can deny the existence of feelings and experiences which the mystics call visions. Indeed almost everyone will agree that what the mystics experienced in their lives are unmistakably to be called mystical experiences. And indeed, who are we to say that the visions (and voices) are not mystical phenomena? The exclusion of visions (and voices) from the class of mystical experience is because both are sensuous experiences. A vision is a piece of visual imagery having colour and shape, and a voice is an auditory image. While a genuine mystical experience is non-sensuous and it is formless, shapeless, colourless, odourless, and soundless. Nevertheless, the exclusion of vision and (voices) from the category of mystical experiences does not entail its exclusion from the sphere of religious experiences.

\section{Arguments against the Visions of God}

We have already seen so far that naturally, vision is too weak to provide any evidence for religious belief. We believed in what our eyes have seen and we can make sure other people believe in the existence of the object, for they normally exist in this world and nothing would intervene in meantime the relation between our perceptions and the objects. In contrast to this, are things or objects which we only believe to exist, because they are nonphysical and non-sensuous? The experience of seeing a vision (and hearing voices) is not wholly accepted by others and could not lead them to form the belief of its existence, on the basis of the reported experience alone. This type of vision involves many complications. How do we know that someone has had direct experience of God or that we ourselves had such an experience? The problem involves verification or falsification of the claims. This will entail another question. If the object perceived is God, is He really present at the time an individual saw Him? Or to put it more clearly, does God's existence require any form or is it formless? Can the experience of God be described or analyzed in terms of any of the elements of sensory-intellectual consciousness? And the last question is: how does the believer know that the vision is really from God and has not been sent to him by devil? These questions are weighty and the answer must concede much to them. We shall deal with all of these problems along with our discussion of this part.

Now we can begin to consider the reasons why the visions of the Infinite Being could not support any claims of its existence and could not form any factual belief at all. It is worth nothing that, some of the religious thinkers have argued that the religious 
experiences cannot be cognitive because they provide support for logically incompatible claims. And, our argument is that, if religious experience were unable to provide any evidence for religious claims, vision would do so. To support this statement, or even to explain it fairly fully, would involve many arguments by religious thinkers. The study finds that there are four reasons or difficulties in constructing religious belief upon visions. These are, firstly because visions are not public but private experiences, secondly because visions conflict with themselves, thirdly because we do not experience the connection between the visions and their supposed objects, and fourthly because there are no criteria for sorting out veridical visions from those which are not veridical.

We begin with the first reason, that visions have no evidential value because they are not public. Of course it would be rational for everybody to believe in his own experiences and in his own perception. But, this is not to say that it is also rational for others to believe in another person's claim on the basis of his perception. Our claims of such perceptions, however reasonableness they may seem to us, should first be examined by others. The evidential value of any claims of the existence of something perceived in the vision would be greatly increased if it has been based upon the rational corroboration of others. For the ordinary test in distinguishing genuine from fantasies, depends on the publicity of the phenomena. In the real-life realm, we can often specify the kind of senseorgans, training, mental set, and the external conditions which will (almost) ensure that if a percept is there, the subject will perceive it. The absence of perceptual experience with the presence of all the enabling conditions implies that the object probably was not present. Someone may claim to see crumbs on white tablecloth, but other people with good eyesight, who know what crumbs look like, who are honest, and who are told to examine the tablecloth, say there are no crumbs, and then the original claim becomes improbable.

Let us assume the case of religious experience. Someone is known to have perceived some persons, and the perceiver claims, on the basis of this experience, to have knowledge of existence of a God. What is needed is that several persons, of normal eyesight, hearing, and intelligence, not predisposed to believe the report of the phenomenon, and so insulated from one another that the effects of suggestibility can be ruled out, should corroborate the apparition. The claimant (the mystic) should regard the agreement of others who have similar experiences as confirming his claims or the veridical character of his own experience. It is possible that if others were to fail altogether to have similar experience, he would take this fact as counting against the cognitive value of his experience. And, in the absence of confirmation from fellow men, the hypothesis that the appearance is delusory must have greater probability than that is veridical. We meet then with the second point, that visions have conflicts in themselves, or they tend to formulate themselves into contradictory statements simultaneously. The point of every human's experience is that it provides a basic for making claims about something other than the experience, of itself. As an example, if we had information about the existence of a deer behind a bush, but when we saw it, it was running away after hearing the noise of our footsteps in the jungle. Although we never know of its existence in the beginning, at that moment, our experience provided us with evidence for the existential claims of something other than itself.

But how do all of these apply to the experience of a distinctly 'mental' kind, a feeling state of an image? It seems to be that the experience cannot, of itself, yield to us any information about anything, other than the experience. We could never know from such experience of vision that they had the character of messages from the divine being, unless, we already possessed a prior knowledge of, and of the way in which, the messages from Divine Being were to be identified. If this is the case, we meet a problem where we must agree that the evidence for the divine existence is anterior to our experience, and, 
moreover, it is not derived from it (Matson 1965: 17). Secondly, we meet with a few other difficulties in the language that the mystics use to express their immediate experience of God. All words in all languages are the products of our sensory-intellectual consciousness and express or describe its elements or some combination of them. But as these elements are not found in this kind of experience, it is felt to be impossible to describe it in any words whatever. In spite of the incommensurability of this experience, the mystics or the theologians do describe their experience in roundabout ways, at the same time telling us that the words they use are inadequate. This raises a serious problem, for 'how do we use the inappropriate terms to express the inexpressible', and 'to describe the indescribable'? And, there may be cases also in which the claimant uses highly technical and probably misunderstood terminology to describe his experience. How could we trust the descriptions of a person who claimed to have 'vision', but we have a reason to prove that he misunderstood and did not understand the terms he uses in his descriptions? Surely, his descriptions cannot be taken as an accurate description of the way the things appeared to him. And, surely, it is rational for others to say that we should not rely on the statements reported by the claimant to form the belief of the existence of something, namely, God.

We move to discern the same difficulty from the question of the meaning of the religious expression. We are not only dissatisfied with the terms used by the experiencing person in their assertions, we are also doubtful about the meaning of those expressions. If the believer defined his assertions with language which he could understand by referring to his past experiences, we could compare the similarity of his utterances, with that which is uses in traditional arguments. For instance we can ask what there is in common between the words God, the angel and so on which he uses them and the words God and the angel as they are used. If the meaning of the words is used in accordance with the religious context, we could approach the same doubt by asking how does the believer claim to know that the being that present to him was the God, the Uncreated, the Imperishable beyond? Both of these questions are difficult to be answered.

The same point can be brought out by considering another difficulty that the inexorable demand of religiously adequate language seems to make of experience of God, a notion that is a contradiction in terms. It is often assumed that our God, is infinite, insensible, imperishable, and has many other characterizations. All that we mean when we use these characterizations is to show that the concept of not being finite, and so on, lies beyond the range of all our positive substantial characterizations. We are unable to comprehend the divine substance by knowing what it is? But we are able to have some knowledge of it by knowing what it is not? The definition of God as Infinite is intended to distinguish between God and everything finite, as well as to distinguish God from everything that is perishable. But, if God is Infinite, Insensible, and Imperishable, how can he be manifested in any, surely, the distinctive definitions between God and others will involve contradictions, for we have to remove those meanings from the world of our experiences (Mac Intyre 1969: 256).

Let us next consider the third reason why we feel fairly certain that visions are too weak to support any existential claims. We have defined the meaning of perception, that it consist of a subject, an object and a connection between both of them, which is the vital part of every perception in distinguishing between a true perception and an imagination. Our sense perception of the physical objects is always veridical, or it might be under circumstances delusive, if some reason could have been shown. Or again, very commonly, we do logically infer the unseen physical object or the no longer seen from the object that we now see. We infer the approaching of a ship from the smoke coming from the funnel, so also we infer the fire from the smoke. We can successfully deduce the invisible from the 
visible object only if we have grounds for believing in a correlation between the occurrence of the sign (the seen) and the thing signified (the unseen). However, we are not at all being sure that we can apply the same rule to the claim of the existence of God from the apparitions. Because we well understand that the logical relations between sense experiences and physical objects are different from the logical relation between mystical experiences and divine object. In order to infer the existence of the divine being from an apparition, we should have an experience of the connection between vision and its supposed objects. But all that we experience is only the vision. We always feel uncertain with visionary experience, unless we can prove the genuineness of an experience of that object, and the reality of the object. Therefore, we have a ground for believing their relation. But all of these will not do. Before we move on to the final reason, a word should be said about the nature of visions. C. B. Martin and others have asserted that there are no tests and check-up procedures which the mystics and others should regard as relevant to a determination of the truth or falsify the claims they make. The visionary experiences therefore, could not be determined with certainty, and their claims are private, not public (as has been shown earlier in the first argument), and self-authenticating.

Finally, we deal with the fourth challenge to the concept of visions. We should never base any ontological claims on vision, for we could never find any concrete rules or criteria in identifying the veridical experiences from those which are not (Mac Intyre 1969: 257). In the case of sense experience, we find it is hard to make any assurance of what the object being reported looks like. As an example, someone who appeared again after an absence of five years would have to be very much changed before we had real doubts as to his identity, but after two or three thousand years it is acre hard to gain credence of his identity. In the religious sphere, however, the case is worse. Suppose that someone sees a vision of Virgin Mary. What he sees has a shape, the shape of a women, and colour, white skin, blue raiment, a golden halo, and so on. And, another man perhaps claims to have seen her in such a place like a Roman Catholic Church. We should at first, consider many questions about these claims, as in the first case of sense experience, before we base or confirm belief in it. We can ask such of the questions like how did the claimant know that it was the Virgin Mary who appeared to him? Can he really be sure that the identification of her is adequate? If it is not, what further identification could there be? And, if it is enough, we could doubt again the resemblances of these identifications with those described in the Bible. What makes him believe that the delivered messages in the vision are the messages from God rather than the wiles of the devil? What criteria does the believer invoke to distinguish true visions from false? And, how do we specify the criteria of personal identity? What are the standard tests that should be used In identifying the objects of the mystical experiences, and could the test be used in examining the mutual experience of vision in other religions of the world? In fact, however good one is trying to answer all the queries, it would never be possible to gain a satisfactory explanation or answer. For no one has authentic evidence of the identification of the appeared object. No appropriate criteria could be applied to them. The only criterion possible is presumably the congruence of the messages accepted in the visions with such theological doctrines as are already believed. If this is admitted, it might be argued that visions could only afford confirmation of belief but could never be the original ground of it. The whole grounds of this discussion points to the conclusion that it is irrational for people to base their belief of the existence of divine being on the basis of visionary experience because it has no evidential value in confirming any belief. The valid ground of religious belief must be found somewhere other than vision, and, if visions are valid for any evidence, it should be remembered that it is for something else rather than for a belief. 


\section{Some Considerations}

We have seen so far that some religious thinkers have shown the non-cognitive status of religious experience, as well as, the visionary experiences of God. It is worthwhile for us to have a brief look into some of the answers from many others against those challenges. Such as answer is rational and valuable, but, nevertheless, we still cannot be happy to say that visions could stand as an independent evidence for our faith. There are several substantial objections that have been brought out by authors of religious philosophers, such as Richard Swinburne, in his book The Existence of God. This philosopher produced two principles - The Principle of Credulity, and the Principle of Testimony - designed to show that immediate religious experience could reach a justified conclusion about the existence of God (Swinburne 1979: 254-276). 'Being well concerned with Swinburne's arguments Caroline Frank Davis in her book The Evidential Force of Religious Experience, tries to show that various types of challenges to the religious experiences ended unsuccessfully in many aspects, and she comes to the conclusion that a quasi-sensory religious experience, namely, a vision, has evidential force by applying her good reason which she called 'A Cumulative Argument'. We shall look first at some of her arguments which might add a great force to the main reasons we have argued. First of all is the argument against the challenges of the non-publicity characteristic of visions, that other people who would have been expected to perceive the alleged percept if it were there, did not have the experience of its seeming to them that the object was there. She argued that in our real-life, we cannot always be sure that the observers fulfilled all the necessary conditions, or, often, just what those necessary conditions are. In the religious case, the situation is even less clear-cut. The fact that people equally attentive and equally well equipped with sense-organs and concepts do not have the same experiences does not count against the veridical of a religious experience. For, if there is a God, one would expect Him to be able to choose to whom He reveals Himself. Thus, one person may have such an experience while his neighbour may not (Davis 1989: 137 \& 241).

This argument, in my view, is a very powerful challenge to our first reason. We feel fully certain that not all external percept are public in the sense that anyone fulfilling certain physical and perceptual conditions will have an experience of its seeming to them that the percept is there, because it is God's freewill to behave and to choose to whom He should reveal Himself. So also we understand that many hidden factors such as faith may be at work. And, because of these aspects - the unexpected and the immeasurability of religious experience - we should stress again, that we could not base any existential claims on vision. Her argument, therefore, is an empty tautology. Turning now to the charge that there are no tests and checking procedures in evaluating mystical experiences as we usually use in examining sense experiences. William J. Wainwright argued that there are two independent kinds to tests - tests which are used to determine the reality of the object of mystical experiences, and tests which are used to determine the genuineness of an experience of that object. In determining the truth of the claim that God is real, one would address oneself to considerations of logic, review the more telling points made by theists and atheists, and so on. The other set of tests containing six criteria, are used to determine the genuineness of an experience of the object. These objections strike on the fourth sort of challenges with greater force. Each of the following six criteria is employed in the Christian community, as well as in other communities.

First, the consequences of a veridical experience must be good, fruitful and editing for the mystic. "By their fruit ye shall know them" (Matthew 7:0). The good effect which the experience has on others also should be considered. These first two tests are moral tests. The third test is that one would not expect a vision of God to lead to insignificant or silly 
talk. The fourth is that we must examine what the mystic says on the basis of his experience whether it agrees or disagrees with orthodox talk. The fifth and sixth tests depend upon the truth of doctrines concerning the holiness and authoritative character of the individual of community in question (Wainwright 1973: 372). Having looked at these new criteria, it is not wrong to say that they are similar to the tests which take things into account like the position of the observer and the condition of his sensory equipment, i.e. the tests which we employ in ordinary perceptual cases. To this end, we can ask whether we could use similar methods to examine the different nature of things. Rationally, the desired result might not be fully satisfied, since it will bring the unique and the not apprehensible mystical experience to a lower condition, similar to sensual experiences. Furthermore, we should ask whether these criteria are adequate enough to examine the effect of the experience. If we have to depend only on these criteria, do they bring us to a confirmation belief of the existence of the cause of the experience; the divine being? It is quite clear that those criteria should not bear the demand of these questions. Although there are many religious thinkers who try to give victory to the status of religious experience such as those that have been made by Swinburne, Wainwright, and Caroline Frank Davis, the fact that visions have no evidential value still cannot be denied. As we have shown above, some of their arguments are unsuccessful in providing any existing claims. Some of their arguments are only successful in very limited cases.

To summarize, I shall say that I am on the same side with those who claim that visions have no cognitive value. To show what I mean, let us have a look at a few more reasons which will bring us with fuller certainty to what we have argued for so long. We can challenge the claim that he has a very unreliable memory, especially regarding his own experience. This is because; under certain circumstances people generally have an inaccurate recall of their own experience. And, we also know that experiences which are very brief, not repeated, unfamiliar, and not easily modified, tend to be difficult to remember and to report. Religious experiences are often of that sort. To make any existing claims on religious experience, as well as vision, therefore, would be meaningless. Theists agree that genuine religious experiences may occur spontaneously to theologically naive and even irreligious subjects. And, it is a common religious belief that subjects of religious experiences can acquire knowledge 'directly', without having to go through the normal channels of experience, authority, or conscious inference. In such situations, who can say that a particular subject has not had the right type of prior experience to be able to make religious claims? Another reason is that religious experiences seem to support incompatible claims. Some mystics claim to perceive the God of Christianity. Others think they taste Nirvana. While others believe they experience the impersonal Brahman. Obviously, the claims were not on the same one because they were based on interpretations of experiences. Surely, these claims, then, provide a reason for discounting their visionary experiences. In evaluating sensual experience, we consider predictions which have been based upon that experience. Successful predictions count for its veridical and unsuccessful predictions count against it. A few predictions do appear to be based upon mystical experience, such as that the soul is immortal, and the claim that human beings will be resurrected. Both claims are verifiable. However, the experiences which would justify them are post-Advent experiences. Neither mystics nor non-mystics can verify these claims in this life. Since these predictions cannot be checked, they cannot be appealed to in order to establish the cognitive value of a particular instance of mystical experience. On the whole, then, it is reasonable to say that visions lack the consistency and predictability needed to form the basis of any factual belief. The ground of belief then is to be found elsewhere, that is in the revelatory events that are already believed.

https://doi.org/10.24035/ijit.2.2012.001 


\section{References}

Al-Quran.

Bassuk, D.E. 1987. The Incarnation of God in Hinduism and Christianity. London: Mac Millan Press.

Charlesworth, M.J. 1972. Philosophy of Religion: the Historic Approaches. London: The Macmillan Press Ltd.

Collin Cobuild English Language Dictionary. 1989. London: William Collins Sons \& Co Ltd. Davis, C.F. 1989. The Evidential Force of Religious Experience. Oxford: The Clarendon Press.

Hick, J. 1989. An Interpretation of Religion. London: MacMillan Press.

Mac Intyre, A. 1969. Vision. In. Antony Flew (ed.). New Essays in Philosophical Theology. London: SCM. Press Ltd.

Martin, C.B. 1973. 'Seeing God'. In William L. Rowe. Philosophy of Religion. USA: Harcourt Brace Jovanovich Inc.

Mason, H.W. 1995. Al-Hallaj. London: Routledge Curzon.

Matson, I.W. 1965. The Existence of God. New York: Cornell University Press.

Peers, E.A. 1957. The Complete Works of St. Teresa of Jesus. London: Sheed and Ward Ltd.

Swinburne, R. 1979. The Existence of God. Oxford: The Clarendon Press.

Wainwright, W.J. 1973. The Cognitive Status of Mystical Experience. In. Rowe, W. L. (ed.). Philosophy of Religion. USA: Harcourt Brace Jovanovich Inc. 